
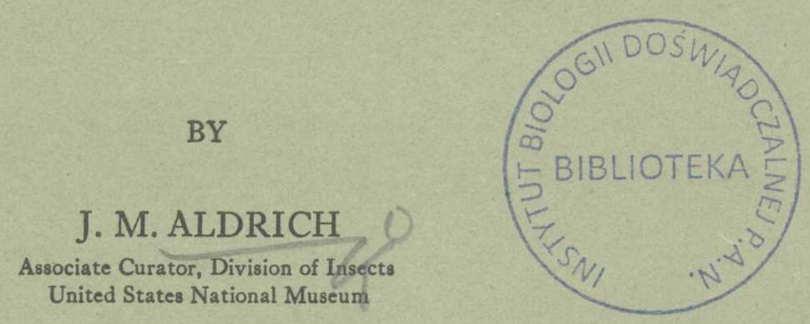

No. 2812. - From the Proceedings of the United States National Museum Vol. 76, Art. 15, pp. 1-13

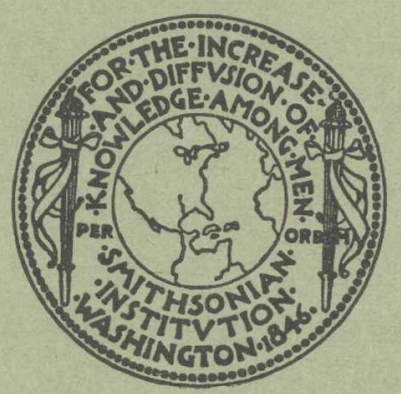

SMITHSONIAN INSTITUTION

UNITED STATES NATIONAL MUSEUM

WASHINGTON, D. C. 
rcin.org.pl 


\section{GLUTOXYS, new genus}

Hypopleurals present; postscutellum wanting; eyes bare; arista long plumose for about two-thirds of its length; third antennal joint long, reaching the vibrissae, which are at the oral margin; antennal axis a little longer than vibrissal; parafacials bare, narrow; facial ridges very flat; front narrow, with a single row of frontals, all somewhat reclinate, reaching to base of antennae; palpi rather small; proboscis fleshy, short. First vein bare, fourth with broadly rounded bend ending exactly in apex; first posterior cell open. Second and third abdominal segments with discals.

Genotype.-Glutoxys elegans, new species.

\section{GLUTOXYS ELEGANS, new species}

Male.-Head and abdomen black; thorax yellow; front at narrow est near middle 0.17 of head width; outer verticals not developed; ocellars very minute; parafrontals silvery, a little wider than median stripe; antennae blackish, third joint nearly three times the second; cheek almost bare, about one-sixth of eye height; palpi dark yellow. Thorax wholly yellow in ground color, including metanotum; viewed from behind with a very distinct silvery band just in front of suture, extending down the side to cover the sternopleura and middle coxa; also with thin silvery pollen extending across the thorax just in front of the scutellum. Chaetotaxy: dorsocentral 3, 3; acrostichal several pairs hair-like, one larger anterior and a prescutellar a little larger; humeral 2; presutural 1; notopleural 2; supraalar 2, (posterior large); intraalar 0 ; sternopleural 2; pteropleural 0 ; hypopleurals about 4 .

Abdomen rather slender, narrow and pointed posteriorly, black in ground color with broad basal silvery bands covering anterior half of second and third segments; fourth segment mostly silvery; first segment with marginal row, smaller along the middle; second with marginal row of six widely separated; third with marginal row of eight; fourth with apical row of about eight and a single pair of discals as in the second and third. Genitalia small.

Legs black, the coxae and basal half or more of all femora yellow. Claws and pulvilli only a little enlarged; middle tibia with one smallish bristle on outer side; hind tibia with only one outer and one inner on the hind side and one on the outer front.

Wings yellowish with a faint dark mark extending from base of third vein forward to costa; third vein with three or four bristles at base; first vein ending directly in front of small cross vein; apical cell open in tip of wing; hind cross vein slightly longer than last section of fifth vein, joining fourth almost in the middle between anterior cross vein and bend. 
Length, $4.2 \mathrm{~mm}$.

Described from seven males collected in Santo Domingo, West Indies, July 5-8, by August Busck.

Type.-Male, Cat. No. 41813, U.S.N.M.

\section{Family TACHINIDAE}

\section{Genus PHOROCERA Robineau-Desvoidy}

Phorocera Robineau-Desvoidy, Myodaires, 1830, p. 131; Dipt. Environs de Paris, 1863, vol. 1, p. 509.-Aldrich and WebBer, Proc. U. S. Nat. Mus., vol. 63 , art. 17,1924 , p. 43.

The genotype is Tachina assimilis Fallen. Aldrich and Webber have discussed the synonymy in detail.

PHOROCERA RUSTI, new species

Mate.-A rather large gray species with heavily striped thorax; the head (except vertex and occiput), and the fourth abdominal segment with deep golden pollen. Front rather wide, at vertex 0.25 of head width. The vertex with gray pollen, which extends as far as the second of the large recurved frontals, where it changes into the dense golden pollen which continues down around the eye and narrowly on the posterior orbit; below the reclinate frontals the much smaller decussate ones are rather scattered but become normally large at the antennae, the lowest ones fully meeting the row of large bristles on the facial ridges. The parafrontal at the second reclinate bristle is slightly wider than the seal-brown middle stripe and much wider near the antennae. Cheek about one-third the eye height, sloping upward anteriorly. Vibrissae at oral margin but considerably above lower edge of head. Antennae black, rather slender, third joint three times the second; arista slender, thickened only on basal fourth. Palpi black. Thorax gray with four very distinct black stripes, the two median extending some distance behind the suture, the outer almost to the scutellum. Acrostichal 3, 3; dorsocentral 3,3 ; presutural 2; sternopleural 2, 1 ; scutellum with three pairs of laterals, apical pair decussate and depressed, more than one-half as long as the longest lateral, a large pair of discals; ground color of scutellum distinctly yellowish. Calypters waxy-white, with white rim. Abdomen with thin pollen, somewhat tessellated, so that irregular patches appear to be shining; fourth segment with very striking dense yellow pollen and yellow ground color; first segment with a very small pair of median marginal bristles; second with a large pair; third with a marginal row slightly interrupted next to the middle pair; fourth segment with an irregular row of discals and a few small apical. Genital segments yellow, very small, the forceps brown, the inner ones close together and rather strongly curved 
forward and rather blunt; the outer forceps a little shorter and wider, the front edge slightly concave and the tip a little more acute. Legs black; tibiae brown, middle tibia with two or three bristles on the outer front side; hind tibia with a row of cilia mixed with several larger bristles. Claws and pulvilli large, the latter grayish. Wing subhyaline with slight brownish tinge along the veins, bend of fourth vein almost rectangular but a little rounded, last section slightly concave; third vein with only two or three hairs at base.

Female.-Vertex 0.29 of the head width, the pollen gray to the second reclinate bristle, changing as in the male to a very deep golden color, almost orange; the two orbital bristles are rather far apart and the parafrontals have fewer and smaller hairs than usual. There is a changeable dark spot in the pollen at the level of the lowest frontals. Abdomen rather more uniformly pollinose than in the male, still with slight tessellation. Middle tibia with one large, and above it one small bristle on outer front side. Wing hyaline.

Length, male, $9.3 \mathrm{~mm}$; female, $8.8 \mathrm{~mm}$.

Described from one male and two females; the former was collected at Tucuman, Argentina, by E. W. Rust, on March 16, 1917, while he was connected with the agricultural experiment station; it bears the label "Est. Exp. A. C. No. 233." The females, one of which is the allotype, were reared at the same place in February, 1929, by Harold E. Box, from cutworms, Remigia repanda; both of these have the puparia with them, and one is returned to Mr. Box.

Type and allotype.-Male and female, Cat. No. 41896, U.S.N.M.

The species agree with the characters of the subgenus Neopales Coquillett.

\section{Genus GAEDIOPSIS Brauer and Bergenstamm}

Gaediopsis Brauer and Bergenstamm. Zweifl. Kais. Mus., pt. 5, 1891, p. 336 ; pt. 6, 1893, p. 190.-Coquillett, Revis. Tachin., 1897, p. 136.Thompson, Canad. Ent., vol. 43, 1911, p. 315.-Adams, in Williston's Manual N. Amer. Dipt., 1908, p. 376.

Poliophrys Townsend, Taxonomy Musc. Flies, 1908, p. 90.

Eugaediopsis Townsend, Proc. U. S. Nat. Mus., vol. 49, 1915, p. 620.

Eugaedia Townsend, Proc. U. S. Nat. Mus., vol. 49, 1915, p. 621.

The type species of Gaediopsis is mexicana Brauer and Bergenstamm; that of Poliophrys is sierricola Townsend; that of Eugaediopsis is Gaediopsis ocellaris Coquillett; and that of Eugaedia is Gaediopsis setosa Coquillett.

\section{GAEDIOPSIS RUFESCENS, new species}

Male.-Ocellar bristles absent, front moderately prominent, the antennal axis slightly longer than the vibrissal; facial ridges with long bristles extending almost up to the arista; parafacials with small hairs on the outer half and an irregular row of small bristles 
extending up the middle, the inner half bare. Vibrissae slightly above the oral margin, which is rather strongly protuberant. Eyes hairy; cheek nearly half the eye height. Palpi yellow, of ordinary size; proboscis short; both pairs of verticals developed; front with rather dense erect dark hair. Ground color of head pale brownish, with thin whitish pollen on the face and around the posterior orbit, in some lights extending on the cheeks and up the anterior orbit nearly to the vertex. Most of the parafrontal area shining translucent brownish in color. Antennae reaching almost to the vibrissae, third joint rather slender, two and one-half times the second. Second aristal joint several times as long as wide, about one-fifth as long as the last joint; the thickening of the arista extending almost to its middle, but not very striking. The basal joints of the antennae dark brown, third joint black.

Thorax reddish brown with the dorsum black except in front of the scutellum, above the wing, and around the humerus, where it is more brownish. Pleura brown anteriorly; lower part of sternopleura, most of the pteropleura, and posterior part blackish. Scutellum reddish brown, with four pairs of marginal bristles, the middle or apical ones nearly as large as the others, slightly decussate. Sternopleural 4; posterior dorsocentral 4; acrostichal 3, 3 .

Abdomen rather broad, with dense erect coarse hair; ground color mostly reddish brown, black immediately behind the scutellum to the end of the second segment; first and second segments with a single pair of marginal bristles, third with a marginal row, fourth with a somewhat irregular row before the middle and another about the posterior two-thirds. Genitalia small and concealed.

Legs including coxae reddish brown, with all the pulvilli and claws decidedly enlarged. Middle tibia on outer front side with four bristles before middle, increasing in size, the first quite small. Hind legs absent.

Wings considerably infuscated on the anterior basal part, the dark color following the veins throughout, noticeably on the anterior cross vein. Hind cross vein almost parallel with wing margin; fourth vein with rounded rectangular bend, thence slightly concave to margin. Third vein with two or three setules at base. Calypters white, the hind ones translucent.

Female.--The single female is somewhat paler than the male, but the mesonotum shows four distinct blackish stripes and a somewhat connected transverse blackish band behind the suture. Eyes very distinctly pilose. Abdomen with more scattered pile, which is not so coarse and erect as in the male. The third segment in some lights shows tessellated thin pale pollen as far as the marginal row of bristles.

Length, male, $9.5 \mathrm{~mm}$; female, $8 \mathrm{~mm}$. 
Described from one male and one female; the male was collected at La Suiza, Costa Rica, March 8, by Pablo Schild, and is from Professor Melander's collection. The female was collected at Amecameca, Mexico, September, 1900, by O. W. Barrett.

Type.-Male, Cat. No. 41810, U.S.N.M.

The species agrees exactly with the generic characters of Gaediopsis, except in the absence of the ocellar bristles. In this respect it agrees with Eugaediopsis Townsend (type ocellaris Coquillett). At present I am inclined to regard the absence of ocellar bristles as not a sufficient character to establish a genus.

\section{Genus EUANTHA Van der Wulp}

Euantha VAN DER WULP, Tijsch. v. Ent., vol. 28, 1885, p. 198; Biologia, Dipt., vol. 2, 1891, p. 248.-Brauer and Bergenstamm, Zweifl. Kais. Mus., pt. 4, 1889 , p. 137 ; pt. 6,1893 , p. 128 -Townsend, Annals and Mag. Nat. Hist., vol. 19, 1897, p. 34-ADAMs, in Williston's Manual N. A. Dipt., 1908, p. 356.-AldRich, Proc. U. S. Nat. Mus., vol. 72, art. 7, 1927, p. 28.

The type species is Dexia liturata Olivier. Townsend ${ }^{1}$ has written that Euantha is a synonym of Sophia Robineau Desvoidy, ${ }^{2}$ but there are great discrepancies between his descriptions and the species of Euantha, so I can hardly believe that the genera are the same. A key to the species has been published by me.

EUANTHA FLAVA, new species

F'emate.-Wholly yellow except the tarsi, which are black, and the tip and hind margin of wing, which are infuscated. The single specimen has been considerably damaged, the lower part of the head pressed in. The front, as in females of the type species, is shining: on both sides of the narrow frontal stripe, but has a narrow pollinose yellow orbit. Third antennal joint a little longer than second, the arista with erect plumosity; vibrissae large; only one pair of vertical bristles; ocellars minute, or perhaps wanting; frontals about six, barely reaching to base of antennae; back of head shining, with yellow hair; only a few coarser black hairs above. Thoracic chaetotaxy: Dorsocentral 3, 3; acrostichal 0, 0; humeral 2, presutural 1, notopleural 2 ; mesopleural with only 1 posteriorly; sternopleural 1 ; hypopleural 1; supraalar 2 ; intraalar 1 ; postalar 2 ; scutellum with 2 lateral, 1 apical, of good size and decussate, no discal. Postscutellum distinct but not large. Calypters very small.

Abdomen fusiform, considerably narrowed at base, one and onehalf times as long as thorax, composed of five evident segments, the basal one more distinct than usual. The first of the larger segments has a pair of large median marginals and three lateral in a diagonal 
row; the second has one pair of discal, one pair of median marginal and one lateral; the third has one discal and an encircling marginal row of 12 ; the fourth has one discal and a marginal row of 10.

Legs moderately slender, the front tarsi distinctly compressed, deep black, and about one-fourth longer than the tibiae. Middle tibia with one bristle on the outer front side, two smaller on the outer hind side, and one flexor; its tarsi are black, not enlarged, and as long as the tibia. Hind femur with five bristles on the upper anterior side, two on the lower posterior; hind tibia with three bristles on inner hind side, three on the outer hind, and two on the outer front side; the tarsi deep black and a little shorter than the tibiae.

Wing large, rather narrowed toward the base, the venation almost as in liturata, but the bend of the fourth vein without appendage. The first posterior cell has the same comparatively wide opening a little before the tip of the wing. There is a small but distinct costa! spine; the apical third of the wing is infuscated, more intensely on the apical part, and a broad dark shadow follows the fifth vein almost from the base to its apex, where it blends with the apical infuscation. The basal two-thirds of the wing, except behind, is dark yellow; the first vein is bare and the third has only one or two minute hairs at the base.

Length, $10 \mathrm{~mm}$.

Described from one specimen, Couchamayo, East Peru (Rosenberg).

Type.-Female, Cat. No. 41811, U.S.N.M.

On account of the condition of the specimen some of the chatotaxy may be incorrect and it is possible that in a well-preserved specimen the calypters would be larger, in other words they may be partially broken off. There would seem to be plenty of characters for a new genus allied to Euantha, but it would be advisable to await the examination of a good specimen before establishing such a genus. There is no question that Euantha is a closely allied genus.

\section{CALLOTROXIS, new genus}

Male only. Dexiid-looking flies of about the build of the common Ptilodexias of the United States, but differing mainly in having pilose eyes, short proboscis, and vibrissae at level of mouth.

Postscutellum and hypopleural bristles present. Antennal axis of head equal to vibrissal. Outer vertical only as the last of the postorbital series of rather long and slender hairs; ocellars only a cluster of hairs; frontals beginning a little before ocellar triangle, none reclinate, about 10 in all, the lowest hardly reaching base of antennae; 
parafacials bare, wide, about half as wide as cypleus, which is flat, a little projecting below, and with a mere trace of a carina above; cheek fully equal to half the eye height; facial ridge with a few coarse hairs above vibrissae; palpi normal, proboscis short, the portion beyond the elbow hardly longer than height of cheek; third antennal joint about twice the second, arista pubescent, the basal joints short. Anterior acrostichals well developed; discal abdominal present. Bend of fourth vein a little angular, first posterior cell more widely open than usual, distinctly before the wing tip.

Genotype.-Callotroxis edwardsi, new species.

CALLOTROXIS EDWARDSI, new species

Male.-Front at narrowest part 0.19 of head width; head with dense cinereous pollen on parafrontals, parafacials, clypeus and orbit; the cheek broadly reddish in front; palpi red or brownish, tips darker; antennae black, base of third joint red; beard mostly dark.

Dorsum of thorax with rather striking white pollen forming a broad margin on each side, the central part shining black but somewhat dissected by indistinct and varying white pollen. When viewed from in front two stripes of pale pollen within the dorsocentral rows extend to the suture and begin again some distance behind and extend to the scutellum. In some angles these marks tend to disappear, the general effect being of a large blackish central spot on mesonotum. Scutellum red with thin white pollen. Chaetotaxy: Acrostichal 3, 3; dorsocentral 3, 3-4; humeral 4; notopleural 2 (with a few long hairs); posthumeral 1; presutural 1; supraalar 3 ; intraalar 3 ; postalar 2 ; sternopleural 2,1 ; scutellum with two lateral and an equally long apical slightly decussate and a small hair-like pair of discals.

Abdomen rather slender, black in ground color, with a conspicuous large elongate reddish spot on each side occupying most of the first to third segments so that the intermediate black portion decreases in width and may almost disappear on the third segment; first segment with a pair of median marginal bristles; second segment with a pair of median marginals and three pairs of discals, one before the other, and mixed with numerous very erect bristly hairs, which do not occur except on the middle region; third segment with the same kind of discals and bristly hairs but with a marginal row of about ten; fourth segment with bristles and erect bristly hairs over the whole dorsal surface; the fifth segment (a narrow intermedinte space preceding the two genital segments) densely covered with erect small bristles, rather striking. The red portion is covered with rather brilliant white pollen matching that on the thorax so that the pattern is quite striking; fourth segment more or less 
infuscated; genitalia mostly reddish in color, of about the same type as in Ptilodexia, the outer forceps being flat and broad, but in this case slightly curved forward to an acute tip; the inner forceps are straight, very slender, and so close together that in one specimen they appear to be united.

Legs black; all the pulvilli large and dark colored; middle tibia with one bristle on outer front side; hind tibia with five or six bristles on outer side, ending a little beyond the middle. Calypters white.

Wings subhyaline; third vein with only four or five hairs at base; hind cross vein oblique and sinuous, joining the fourth vein only a little before the bend; last section of fifth vein less than half the hind cross vein.

Length, $10.5 \mathrm{~mm}$.

Described from two males. The type was received from Prof. D. S. Bullock, Angol, Chile, who reared it October 29, 1928, "from roots of basket willow"; the paratype was collected at Conception, Chile, December 26-28, 1926, by F. Edwards and M. Edwards, after whom the species is named; it was collected by a British Museum expedition and the specimen is returned to that institution.

\section{Type.-Cat. No. 41651, U.S.N.M.}

This species bears a striking resemblance in its brilliant pollinose pattern to Huascarodexia pulchra Townsend ${ }^{3}$ described from a single female specimen collected in Peru. Townsend's species, (female, male unknown), has the arista short plumose, the third antennal joint considerably longer, parafacials much wider, well-developed proclinate ocellars, proboscis somewhat longer, and the abdomen with very feebly developed discals. Both genera have pilose eyes, an unusual character in species so distinctly dexiine.

\section{CARTOCOMETES, new genus}

Eyes bare; front prominent, broad in both sexes; third antennal joint twice the second, reaching nearly to vibrissae, which are far apart at oral margin; second aristal joint a little elongate, about onesixth of the third; ocellars large, proclinate and divergent; frontal bristles reaching to middle of second antennal joint; proclinate orbitals present in both sexes; parafacials with numerous quite long hairs; face a little concave, the ridges low, with three or four bristles above the vibrissae, not reaching middle of the face; cheek about two-fifths eye height; palpi and proboscis normal; antennal axis almost double the vibrissal. Postscutellum and hypopleural bristles present. First posterior cell open in apex of wing; the fourth vein with broadly rounded curve; first vein bare; third with sparse, long,

Ins. Ins. Menst., vol. 6, 1918, p. 176. 
erect hairs. Abdomen broad; discals on abdominal segments; outer side of all tibiae in female with numerous long slender bristles, less abundant in male.

Genotype.-Cartocometes io, new species.

CARTOCOMETES IO, new species

Female.-Front wide, 0.45 of head width, the frontal stripe occupying about one-half of this, rather light red in color; lower part of head yellowish red, antennae of the same color; frontal bristles six, the uppermost not appreciably reclinate; the usual two orbital bristles present; parafacials with numerous black hairs; back of head with some small pale hairs on the lower part not very conspicuous; palpi yellow.

Thorax black on the disk, broadly reddish yellow on the sides and pleurae, the latter, however, somewhat mottled with black behind. Chaetotaxy: acrostichal 3, 3 (the hindmost rather large); dorsocentral 2, 3; humeral 4; presutural 2; notopleural 2; supraalar 1; intraalar 4; 2 between supraalar and intraalar; postalar 2 (the inner much larger); sternopleural 2, 1; pteropleural 1 small; scutellum with 3 lateral pairs and a rather large decussate apical, discal poorly developed, postscutellum well developed, black like the remainder of the metanotum, the scutellum being reddish yellow. Calypters white, the rim slightly infuscated on the inner side.

Abdomen rather flat, hind edges of all the segments faintly reddish, the surface somewhat variably mottled with light and dark pollen. First segment rather long with a marginal pair, and in one specimen a single discal ; second segment with a discal pair, and a marginal row of about 14; third with two pairs of irregular discals and several hair-like bristles scattered over the surface without regular order, hind margin without a distinct row; fourth segment with irregular ereat scattered hair-like bristles beginning at the front edge, no distinct marginal row. The sides of the abdominal segments have some irregularly arranged long bristles.

Legs, including tarsi, yellow, the femora with traces of infuscation; all the tibiae with strikingly long hair-like bristles arranged in several irregular rows; tarsi rather strikingly short, pale to the tip.

Wings subhyaline, the hind cross vein erect, joining fourth vein hardly beyond the middle between small cross vein and bend, the latter very broadly rounded; the erect coarse hairs of the third vein large, extending far beyond the cross vein in one specimen but only to it in the other.

Length, $5 \mathrm{~mm}$.

Male.-Front at vertex 0.43 of head width, more prominent than in female; femora black in ground color except broadly on underside apically; claws and pulvilli small. Genitalia of unique struc- 
ture; the inner forceps forming a short heart- shaped pad like structure covered with dense hairs, the notch being next the anus and the tip very blunt; the outer forceps long and slender, shining black, curving toward each other at tip; penis upright and blunt, the back black, the front with white swelling on basal half and the apex with narrow white collar.

Described from one male and five female specimens. The type, female, is from Riverhead, N. Y., collected May 3, 1927, by H. C. Huckett. The allotype male and one paratype female were reared at Newbury, Vt., from Malacosoma disstria on April 24-29, 1925 (Gip. Moth Lab. No. 10081K6) ; one female from the same host at Dedham, Mass., May 4, 1916 (G. M. L. No. 10001C18); another from the same host at Bradford, Vt., April 27, 1925 (G. M. L. No. 10081K6a); and another from Malacosoma americanum at Melrose Highlands, Mass., May 11, 1916 (G. M. L. No. 10000i).

\section{Type.-Female, Cat. No. 41814, U.S.N.M.}

The female of the species differs from all others known to me in the numerous long hair like bristles occurring on all the tibiae; the only species approaching it is Metopomuscopteryx tibialis Coquillett, which differs in several important characters. The nearest relative I can discover is Chromatocera setigena Coquillett, which, however, has ordinary tibiae, hairy eyes, the fourth vein with rectangular bend and ending considerably before the tip.

\section{TROPHOMYIA, new genus}

Allied to Tachina, agreeing with the genotype (grossa Linnaeus), in being large and robust, with stout but not very numerous spines; parafacials hairy, vibrissae above oral margin; second antennal joint longer than third; vibrissal axis equal to antennal; postalar callosites with tuft of bristles which blend with a depressed marginal row on scutellum; and in many details. It differs from grossa in having the face flat, the oral margin not projecting, the facial ridges more bowed outward, strongly converging below, bristles of thoracic disk much reduced except at sides and behind, etc.

Eyes bare; second joint of arista elongated, third bare; ocellar bristles absent or small and proclinate; palpi normal, proboscis short, no discal bristles on abdomen except last segment; second to fourth sternites with a group of stout spines, none on inflexed ends of tergites; prosternum bare.

Genotype.-Trophomyia pictipennis, new species.

TROPHOMYIA PICTIPENNIS, new species

Male.-Front 0.28 of head width at vertex, thence widening rapidly; head wholly deep golden pollinose, the frontal stripe more reddish; parafacials with thin yellow to blackish pile; antennae reddish 
yellow, third joint usually infuscated apically, a little more than half as long as second; palpi yellow, with dense short black hair; outer vertical small; one reclinate frontal above, two to four proclinate orbitals; lower frontals broadly diverging, extending as low as base of second antennal joint; upper frontals small and sparse; facial ridges flat, with two or three small bristles next to vibrissae, extending almost laterally; cheek about equal to eye height; the space inclosed by the suture approaches a circle in form, and the parafacial is equal in width to about one-third of its diameter. Back of head with dense deep golden ruff. Thorax black, subshining, pollinose only a little on front edge, humeri and adjacent parts deep reddish in ground color; calypters golden, the hind one bare. Scutellum with about five pairs of bristles on margin, the middle pair smaller and variable; sternopleural 2, 1. Abdomen dark reddish brown to almost black, shining; second and third segments with a little very thin pollen on sides at base, fourth with large lateral basal spots of silvery pollen, not very dense. First segment without marginals, second with a widely spaced upright spiny pair, third with marginal row of a dozen or more, fourth from the middle with numerous spiny bristles; sternites as described. Genital segments small, brownish red.

Legs black, shining, rather stout, the tarsi quite short, pulvilli yellow, conspicuous but not remarkably long; middle tibia with several bristles on outer front side, hind ones a little bowed, with dense cilia irregularly arranged on hind side.

Wings strikingly marked, yellow to the small cross vein, the remainder dark brown along the costa, fading to a slight infuscation behind, the brown however continuing along the veins; fourth vein rectangular at bend, then concave, ending far before tip of wing; third vein with a few hairs at base.

Female.-Front 0.28 of head width at vertex; third antennal joint less than half the second; abdomen wholly shining; pulvilli a little smaller.

Length, male, 16 ; female, $17.5 \mathrm{~mm}$.

Described from seven males and two females; the males were received through J. R. Malloch from the Federated Malay States Museum, and were collected by H. M. Pendlebury at Selangor, Bukit Kutu, Federated Malay States, altitude 3,500 feet. The females were received from the Vienna Natural History Museum, and are labeled "Rio Demerara, Heyne." They are old specimens; I had described the species from them as South American, when Mr. Malloch saw them and told me he had received the same species from the Orient. On bringing the two lots together it was apparent that the locality label on the females must be erroneous. 
The species has a striking superficial resemblance, especially in the color of the wings, to Nemoraea tropidobothra Brauer and Bergenstamm, also oriental, which however is a true Nemoraea in having the hind calypters pilose above, a very unusual Tachinid character. Another species which must be very similar is Oxyrutilia jacobsoni 'Townsend ${ }^{4}$ described from a single female collected at Sumatra. It is said to have a large facial carina and apparently can not be congeneric with the present species.

One male, and one female, type and allotype, are retained, the paratypes returned to the museums from which they came.

Type.-Male, Cat. No. 40979, U.S.N.M.

4 Supplementa Ent., vol. 14, 1926, p. 31.


U. S. GOVERNMENT PRINTING OFFICE: 1929 
rcin.org.pl 
rcin.org.pl 
1 